\title{
Teaching NeuroImage: Human Polymerase Gamma Gene (POLG) Disorder Presenting as Refractory Status Epilepticus
}

Hernan Nicolas Lemus, MD, Dewitt Pyburn, MD, Clover Youn, DO, John Liang, MD, Arash Yousefi, MD, Rachel Saunders-Pullman, MD, MPH, Gabriela Tantillo, MD, Lara Marcuse, MD, and Madeline Fields, MD Neurology ${ }^{\circledR}$ 2021;97:e747-e748. doi:10.1212/WNL.0000000000012105

Figure 1 EEG and MRI of Index Patient

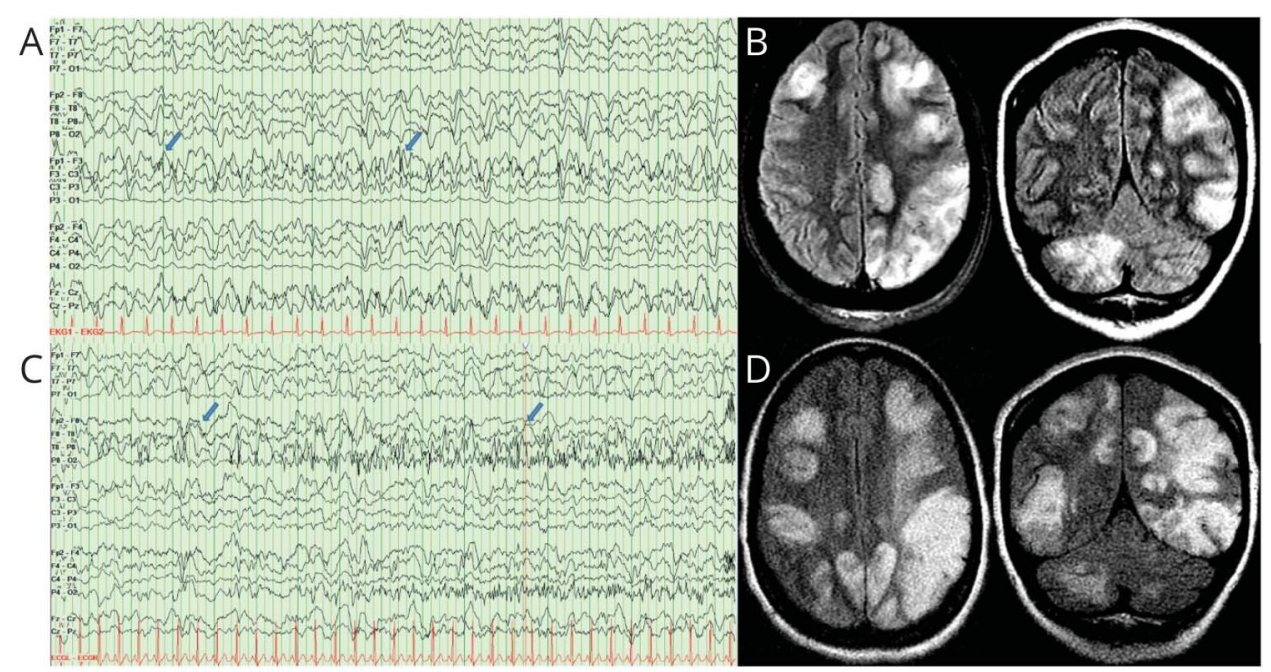

(A) EEG on day of admission shows a longitudinal bipolar montage with left frontocentral focal status epilepticus (blue arrows). (B) Fluid-attenuated inversion recovery (FLAIR) MRI shows multifocal hyperintensities. (C) EEG later in the hospital course shows right temporo-occipital region seizures (blue arrows). (D) FLAIR MRI shows worsening of the hyperintensities with involvement of the right hemisphere.

A 31-year-old woman with severe childhood-onset dysmotility syndrome was admitted for encephalopathy and seizures. Video EEG demonstrated electrographic seizures of multifocal onset refractory to multiple antiseizure medications (figure 1, A and C). MRI of the brain revealed multiple hyperintensities (figure 1B) that progressed (figure 1D). Infectious, immunologic, and neoplastic workup was unremarkable. A comprehensive epilepsy panel demonstrated a human polymerase gamma gene $(P O L G)$ likely pathogenic variant, c.3401 (c.3401A $>G)$, previously reported as recessive, and a novel variant of unknown significance, c.2725 (c.2725 G>A). We hypothesize both variants are predicted to act in a compound heterozygous fashion. POLG disorders present with a discrete phenotype in adults; diagnosis is critical as valproate can precipitate liver failure ${ }^{1,2}$ (figure 2).

\section{Acknowledgment}

The authors thank George A. Diaz, MD, PhD, for genetic advice on the patient.

\section{Correspondence}

Dr. Lemus

Hernannicolas.

lemusesquivel@mountsinai.org

\section{MORE ONLINE}

\section{Teaching slides}

links.lww.com/WNL/

B394

From the Department of Neurology (H.N.L., D.P., C.Y., A.Y., R.S.-P.), Icahn School of Medicine at Mount Sinai Downtown; Department of Neurology and Neurosurgery (J.L.), Icahn School of Medicine at Mount Sinai West; and Department of Neurology (G.T., L.M., M.F.), Icahn School of Medicine at Mount Sinai Hospital, New York, NY.

Go to Neurology.org/N for full disclosures. Funding information and disclosures deemed relevant by the authors, if any, are provided at the end of the article. 


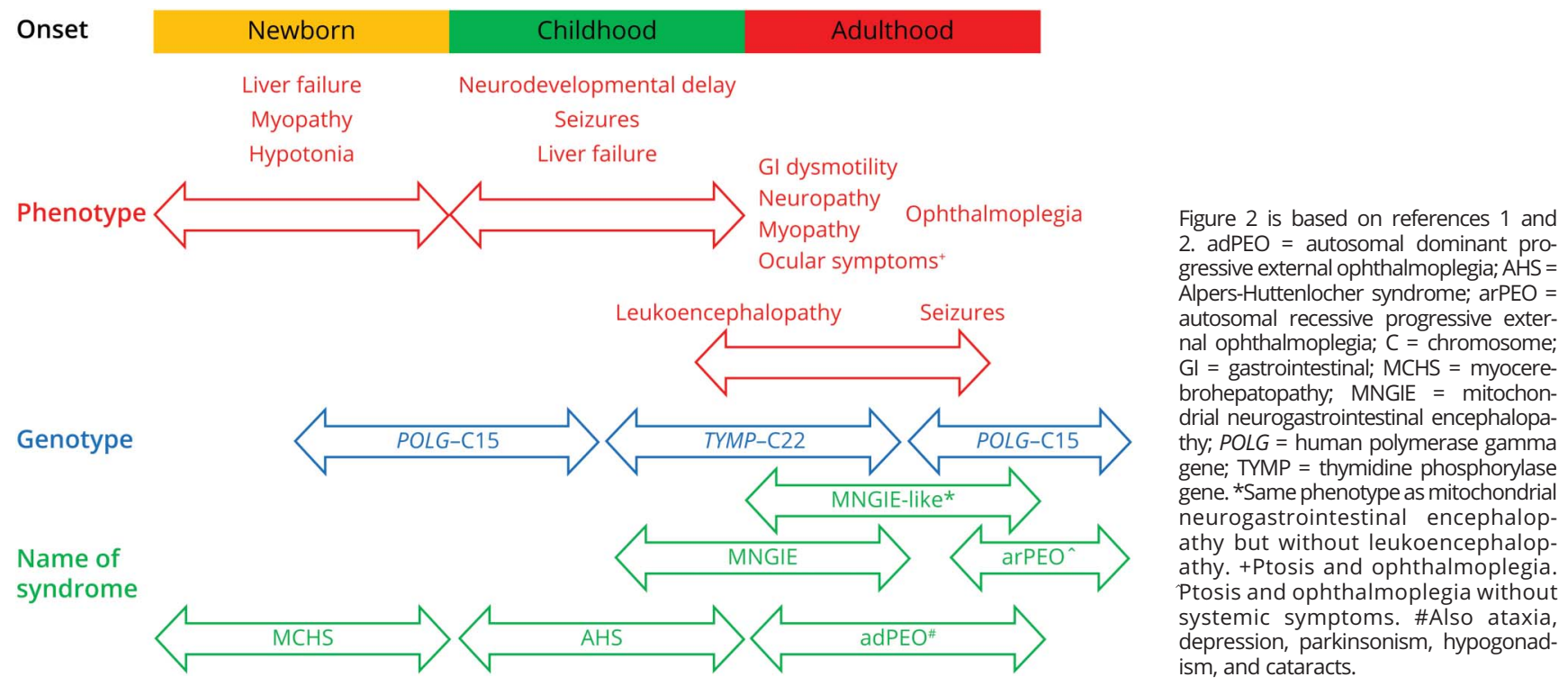

\section{Study Funding}

No targeted funding reported.

\section{Disclosure}

Dr. Lemus, Dr. Pyburn, Dr. Youn, Dr. Liang, and Dr. Yousefi report no disclosures relevant to the manuscript. Dr. SaundersPullman reports support from NIH U01-NS107016-01A1, Empire Clinical Research Investigator Program, the Bigglesworth Family Foundation, and Bachmann-Strauss Professorship. Dr. Tantillo previously held shares in a diversified index health care exchange traded fund unrelated to this study (2019). Dr. Marcuse and Dr. Fields report no disclosures relevant to the manuscript. Go to Neurology.org/ $\mathrm{N}$ for full disclosures.

\section{Appendix Authors}

\begin{tabular}{lll}
\hline Name & Location & Contribution \\
\hline $\begin{array}{l}\text { H. Nicolas } \\
\text { Lemus, MD }\end{array}$ & $\begin{array}{l}\text { Icahn School of } \\
\text { Medicine at Mount } \\
\text { Sinai Downtown }\end{array}$ & $\begin{array}{l}\text { Designed and conceptualized } \\
\text { study, drafted the manuscript } \\
\text { for intellectual content }\end{array}$ \\
\hline $\begin{array}{l}\text { Dewitt Pyburn, } \\
\text { MD }\end{array}$ & $\begin{array}{l}\text { Icahn School of } \\
\text { Medicine at Mount } \\
\text { Sinai Downtown }\end{array}$ & $\begin{array}{l}\text { Designed and conceptualized } \\
\text { study, drafted the manuscript } \\
\text { for intellectual content }\end{array}$ \\
\hline $\begin{array}{l}\text { Clover Youn, } \\
\text { DO }\end{array}$ & $\begin{array}{l}\text { Icahn School of } \\
\text { Medicine at Mount } \\
\text { Sinai Downtown }\end{array}$ & $\begin{array}{l}\text { Drafted the manuscript for } \\
\text { intellectual content }\end{array}$ \\
\hline
\end{tabular}

Appendix (continued)

\begin{tabular}{|c|c|c|}
\hline Name & Location & Contribution \\
\hline John Liang, MD & $\begin{array}{l}\text { Icahn School of } \\
\text { Medicine at Mount } \\
\text { Sinai West }\end{array}$ & Critical review of the manuscript \\
\hline $\begin{array}{l}\text { Arash Yousefi, } \\
\text { MD }\end{array}$ & $\begin{array}{l}\text { Icahn School of } \\
\text { Medicine at Mount } \\
\text { Sinai Downtown }\end{array}$ & Critical review of the manuscript \\
\hline $\begin{array}{l}\text { Rachel } \\
\text { Saunders- } \\
\text { Pullman, MD, } \\
\text { MPH }\end{array}$ & $\begin{array}{l}\text { Icahn School of } \\
\text { Medicine at Mount } \\
\text { Sinai Downtown }\end{array}$ & Critical review of the manuscript \\
\hline $\begin{array}{l}\text { Gabriela } \\
\text { Tantillo, MD }\end{array}$ & $\begin{array}{l}\text { Icahn School of } \\
\text { Medicine at Mount } \\
\text { Sinai Hospital }\end{array}$ & Critical review of the manuscript \\
\hline $\begin{array}{l}\text { Lara Marcuse, } \\
\text { MD }\end{array}$ & $\begin{array}{l}\text { Icahn School of } \\
\text { Medicine at Mount } \\
\text { Sinai Hospital }\end{array}$ & Critical review of the manuscript \\
\hline $\begin{array}{l}\text { Madeline } \\
\text { Fields, MD }\end{array}$ & $\begin{array}{l}\text { Icahn School of } \\
\text { Medicine at Mount } \\
\text { Sinai Hospital }\end{array}$ & Critical review of the manuscript \\
\hline
\end{tabular}

\section{References}

1. Rahman S, Copeland WC. POLG-related disorders and their neurological manifestations. Nat Rev Neurol. 2019;15(1):40-52.

2. Hikmat $\mathrm{O}$, Tzoulis $\mathrm{C}$, Chong WK, et al. The clinical spectrum and natural history of early-onset diseases due to DNA polymerase gamma mutations. Genet Med. 2017; 19(11):1217-1225 


\section{Neurology}

Teaching NeuroImage: Human Polymerase Gamma Gene (POLG) Disorder Presenting

Hernan Nicolas Lemus, Dewitt Pyburn, Clover Youn, et al.

Neurology 2021;97;e747-e748 Published Online before print April 30, 2021

DOI 10.1212/WNL.0000000000012105

This information is current as of April 30, 2021

\section{Updated Information \&} Services

References

Subspecialty Collections

Permissions \& Licensing

Reprints including high resolution figures, can be found at: http://n.neurology.org/content/97/7/e747.full

This article cites 2 articles, 0 of which you can access for free at: http://n.neurology.org/content/97/7/e747.full\#ref-list-1

This article, along with others on similar topics, appears in the following collection(s):

EEG

http://n.neurology.org/cgi/collection/eeg_

EEG; see Epilepsy/Seizures

http://n.neurology.org/cgi/collection/eeg_see_epilepsy-seizures

Gastrointestinal

http://n.neurology.org/cgi/collection/gastrointestinal

Status epilepticus

http://n.neurology.org/cgi/collection/status_epilepticus

Information about reproducing this article in parts (figures,tables) or in its entirety can be found online at:

http://www.neurology.org/about/about_the_journal\#permissions

Information about ordering reprints can be found online:

http://n.neurology.org/subscribers/advertise

Neurology ${ }^{\circledR}$ is the official journal of the American Academy of Neurology. Published continuously since 1951, it is now a weekly with 48 issues per year. Copyright @ 2021 American Academy of Neurology. All rights reserved. Print ISSN: 0028-3878. Online ISSN: 1526-632X.

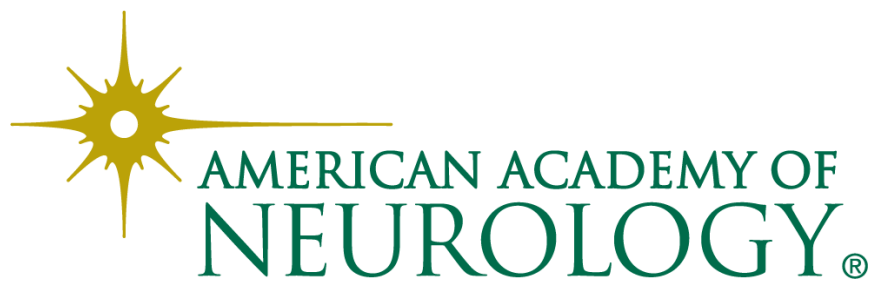

